\title{
Oceanography
}

CITATION

Kappel, E.S., and J. Ramarui. 2014. Quarterdeck. Looking back and forward.

Oceanography 27(4):5, http://dx.doi.org/10.5670/oceanog.2014.95.

DOI

http://dx.doi.org/10.5670/oceanog.2014.95

COPYRIGHT

This article has been published in Oceanography, Volume 27, Number 4, a quarterly journal of The Oceanography Society. Copyright 2014 by The Oceanography Society. All rights reserved.

USAGE

Permission is granted to copy this article for use in teaching and research. Republication, systematic reproduction, or collective redistribution of any portion of this article by photocopy machine, reposting, or other means is permitted only with the approval of The Oceanography Society. Send all correspondence to: info@tos.org or The Oceanography Society, PO Box 1931, Rockville, MD 20849-1931, USA. 


\section{Looking Back and Forward}

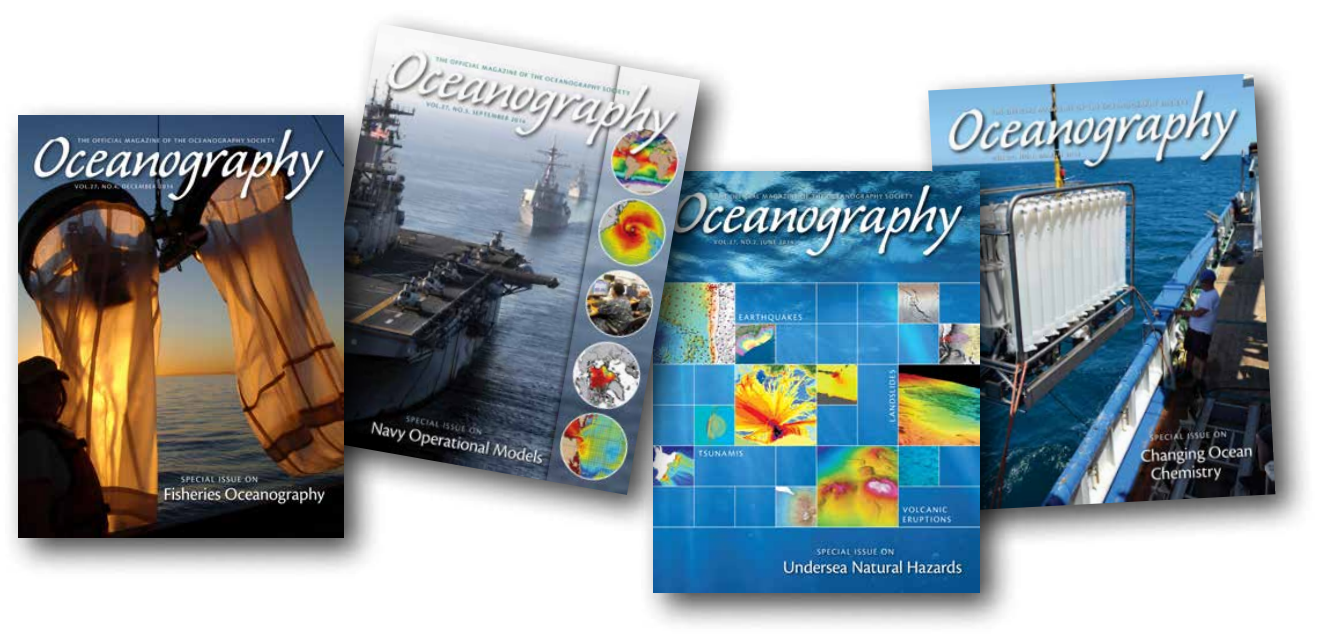

This December issue of Oceanography concludes a productive year for The Oceanography Society (TOS) and the magazine. TOS co-sponsored or coordinated three big meetings in 2014: the Ocean Sciences Meeting (with AGU and ASLO) in February in Hawaii, the Ocean Optics XXII meeting in October in Maine, and the Second International Ocean Research Conference (with the International Oceanographic Commission-UNESCO) in November in Barcelona (see summaries of the latter two meetings on pages 182-183 in this issue). TOS is already involved in preparations for the next Ocean Sciences Meeting to be held in New Orleans in February 2016 (see ad on the back inside cover). Other TOS projects include transitioning to a new membership database system early next year that should streamline the membership renewal process as well as communications.

The Oceanography staff has been working very hard to bring our readers interesting special issue topics and supplements. Articles in this issue cover several aspects of the important field of fisheries oceanography, showing how scientists are using the latest technology, long time series of observations, and new models that include environmental variables to improve fisheries management in a changing environment. Our December issue also includes a stand-alone supplement on women in oceanography, reviewing the progress that has been made on retaining women in the field in the last decade, and, like the March 2005 special issue on this topic (http://tos.org/ oceanography/archive/18-1.html), a compendium of one-page autobiographies contributed by women scientists worldwide. These autobiographies demonstrate the richness of our field and the challenges faced by oceanographers-both women and men-in pursuing fulfilling careers.
Two of our upcoming issues also include supplements. The March 2015 issue on the experiment called Salinity Processes in the Upper ocean Regional Studies (SPURS) will be accompanied by our fifth review of the most recent Nautilus field season. Our June special issue on Emerging Themes in Ocean Acidification Science will bring you our first electronic-only supplement; it will include synthesis papers from the Second International Ocean Research Conference plenary talks, sessions, and workshop. To keep abreast of upcoming special issues of Oceanography, go to http://tos.org/oceanography/issues/ upcoming.html.

Finally, we thank Mark Abbott, our outgoing TOS president, as well as Mike Roman, TOS past-president, for the outstanding leadership they have provided the Society over the last several years. Susan Lozier, who takes the helm on January 1, will have a solid foundation upon which she can continue to build an even stronger Society serving our community.

With all of the exciting TOS happenings, we hope you have remembered to renew your membership (https://netforum. avectra.com/eWeb/StartPage.aspx?Site=TOS). Please also consider sponsoring a student (http://tos.org/join_tos.html). Regular membership is still only $\$ 60$, and student membership is $\$ 30$ per year.

Best wishes for a prosperous and productive new year!

- Ellen S. Kappel, Oceanography Editor, and Jennifer Ramarui, TOS Executive Director 